\title{
FIRST GONADAL MATURATION OF Pinirampus pirinampu (SILURIFORMES: PIMELODIDAE) IN THE PANTANAL, MATO GROSSO DO SUL STATE, BRAZIL
}

\author{
PEIXER, J. ${ }^{1}$, MATEUS, L. A. F. ${ }^{2}$ and RESENDE, E. K. ${ }^{3}$ \\ ${ }^{1}$ Department of Ecology, Universidade Estadual Paulista - UNESP, Júlio de Mesquita Filho, \\ Avenida 24 A, 1515, C. P. 199, CEP 13506-900, Rio Claro, SP, Brazil \\ ${ }^{2}$ Department of Animal Production, School of Veterinary Medicine, Federal University of Mato Grosso, \\ Av. Fernando Corrêa, s/n, CEP 78060-900, Cuiabá, MT, Brazil \\ ${ }^{3}$ Empresa Brasileira de Pesquisa Agropecuária/CPAP, EMBRAPA, \\ Rua 21 de setembro, 1880, CEP 79320-900, Corumbá, MS, Brazil \\ Correspondence to: Janice Peixer, Department of Ecology, Universidade Estadual Paulista - UNESP, \\ Júlio de Mesquita Filho, Avenida 24 A, 1515, C. P. 199, CEP 13506-900, Rio Claro, SP, Brazil, \\ e-mail: janicepx@hotmail.com \\ Received March 11, 2004 - Accepted May 19, 2004 - Distributed February 28, 2006
}

(With 3 figures)

\begin{abstract}
Information regarding the reproductive cycle of commercially exploited fish species is extremely important for their appropriate management. The reproductive size of Pinirampus pirinampu (Spix, 1829) was determined for a population studied in the Pantanal wetlands of western Brazil. Samples were taken in September, October, and December 1997, and in February and March 1998. Gonadal stages were macroscopically determined and a monthly gonadossomatic index (GSI) was used to determine the breeding period. The length of the first gonadal maturation was determined by classifying male and female adults and immature fish into length classes. The data on the adult individuals were plotted on graphs and the median values estimated to find the length at which $50 \%$ of the individuals reached maturity $\left(\mathrm{L}_{50}\right)$. $\mathrm{L}_{100}$ was also determined. Males and females in the gonadal maturation process were recorded from October on, and the highest frequency was found to occur in February. Individuals with empty gonads occurred from February onwards. The GSI showed that gonadal development began in September and reached its peak in February. The $\mathrm{L}_{50}$ was $574 \mathrm{~mm}$ for females and $536 \mathrm{~mm}$ for males, while the $\mathrm{L}_{100}$ was $590 \mathrm{~mm}$ for females and $580 \mathrm{~mm}$ for males.
\end{abstract}

Keywords: reproduction, Pinirampus pirinampu, Pantanal.

\section{RESUMO}

\section{Primeira maturação gonadal do Pinirampus pirinampu (Siluriformes: Pimelodidae) no Pantanal de Mato Grosso do Sul, Brasil}

Informações sobre o ciclo reprodutivo de espécies exploradas pela pesca são imprescindíveis para o seu manejo adequado. O tamanho de início da atividade reprodutiva do Pinirampus pirinampu (Spix, 1829) foi determinado. Os exemplares foram capturados em setembro, outubro e dezembro de 1997 e fevereiro e março de 1998. O estádio de desenvolvimento gonadal foi identificado macroscopicamente.

O índice gonadossomático médio (IGS), calculado mensalmente, foi utilizado como indicador da época de desova. Para determinação do comprimento da primeira maturação gonadal agruparam-se, separadamente, machos e fêmeas por classes de comprimento em imaturos e adultos. Os resultados referentes aos indivíduos adultos foram lançados em gráficos e a mediana correspondeu à estimativa do comprimento no qual $50 \%$ dos indivíduos atingem a maturidade $\left(\mathrm{L}_{50}\right)$. Foi também determinado o $\mathrm{L}_{100}$, estimativa do comprimento em que todos os indivíduos estão aptos à reprodução. 
Machos e fêmeas em processo de maturação gonadal foram encontrados a partir de outubro, com maior frequiência em fevereiro, e, somente a partir deste mês, foram encontrados indivíduos com gônadas esvaziadas. $\mathrm{O}$ índice gonadossomático mostrou que a partir de setembro inicia-se o processo de desenvolvimento gonadal, com seu valor máximo em fevereiro. $\mathrm{O} \mathrm{L}_{50}$ para fêmeas foi $574 \mathrm{~mm}$ e para machos foi $536 \mathrm{~mm}$. $\mathrm{O} \mathrm{L}_{100}$ para fêmeas foi $590 \mathrm{~mm}$ e para os machos, $580 \mathrm{~mm}$.

Palavras-chave: reprodução, Pinirampus pirinampu, Pantanal.

\section{INTRODUCTION}

The Pantanal is a large floodplain where periodic flooding is caused by the rising of the rivers of the Paraguay River basin. The basin's total area is $500.000 \mathrm{Km}^{2}$, of which $361.666 \mathrm{Km}^{2}$ lie in Brazilian territory. The Pantanal floodplain covers an area of approximately $138.183 \mathrm{Km}^{2}$ (Brasil, 1997).

The annual cycle of alternating periods of flooding and drought is the most important phenomenon in the Pantanal wetlands and the main factor influencing fish production. This factor is particularly important for species that use the entire extent of the flooded area during their life cycle, as in the case of migratory fish, which gather in schools in the dry season to swim upstream to the headwaters, where they spawn at the onset of the rainy season. After spawning, the adults and juveniles drift downstream, reaching the flooded areas used as foraging, growth sites and shelter against predation. The Pimelodidae Pinirampus pirinampu (Spix, 1829) is included among these species, which is also found in the Apure River, a tributary of the Orinoco (Lowe-Mcconnell, 1987), and in the Paraná River basin, mostly in lotic sites (Agostinho et al., 1997). Although this species is included in the fishery statistics on the Paraguay River basin (Catella, 2001; Mateus, 2003), the literature lacks reports on its reproductive biology, which is important to understand the population dynamics. Information such as the reproductive period and size at first reproduction is also important to define and implement management procedures for the species. Moreover, size at first reproduction is crucial information for the definition of the minimum capture size.

Measures aimed at regulating fishery activities are undoubtedly needed to maintain the natural fish stocks and for their rational exploitation. Minimum capture size has been one of the most commonly employed management alternatives. According to Harley et al. (2000), the establishment of a minimum capture size is an instrument that can serve to protect juvenile fish, maintain the reproductive stock and control the capture size. Thus, although such measures are part of Brazil's state fishing laws, they are not based on studies about the species' reproductive biology. Therefore, this study aimed to estimate the size of the first gonadal maturation of Pinirampus pirinampu, providing scientific support to determine its minimum capture size in the Pantanal wetlands of Brazil.

\section{MATERIALS AND METHODS}

Specimens were captured in the months of September, October and December 1997, and February and March 1998, the periods indicated by Resende et al. (1995) and Ferraz de Lima (1981) as being the reproductive periods of the migratory species in Brazil's Pantanal region.

The study was carried out in an area near the Parque Nacional do Pantanal Mato-Grossense, in the Cuiabá River (September and October 1997, February and March 1998) and in the Paraguay River (December 1997). Samples were obtained through experimental fishery, using cast nets and gill nets of different mesh sizes, and specimens captured by professional fishermen using fishhooks of various sizes.

The following data were recorded for each individual: total length, standard length, total weight, gonad weight, sex, and stage of gonadal development.

The stage of gonadal development was macroscopically identified according to the following scale: stage I - immature; stage II - maturing process; stage III - mature; stage IV - empty; and stage V - resting (Vazzoler, 1996).

The gonadosomatic index (GSI) was obtained according to Vazzoler et al. (1989) apud Vazzoler (1996). 


$$
G S I=\frac{W_{g}}{W_{b}} * 100
$$

where

$$
W g=W t-W g
$$

and

$W_{\mathrm{g}}=$ gonad weight

$W_{\mathrm{c}}^{\mathrm{g}}=$ body weight

To determine the length of the first gonadal maturation, we classified males and females by length into immature (stage I) and adults (stages II, III, IV). The length of the first gonadal maturation $\left(\mathrm{L}_{50}\right)$, which corresponds to the estimated length at which $50 \%$ of the individuals reach maturity (Vazzoler, 1996), was obtained by plotting on graphs the adult male and female length classes and by estimating the median values. $\mathrm{L}_{100}$, which corresponds to the frequency at which $100 \%$ of adults reach maturity, was also thus obtained.

\section{RESULTS}

A total of 118 individuals were captured, of which $46(39 \%)$ were females and $72(61 \%)$ were males (Table 1). Most of the individuals were captured in October.

Fig. 1 shows the distribution frequency of the gonadal development stages for males and females. Immature females (stage I) were not observed in February, and were more frequent in September. The gonadal maturation process (stage II) of the females occurred from October to March. Mature females (stage III) were not captured, and empty gonads (stage IV) were observed after February.
Females in the resting period (stage $\mathrm{V}$ ) were more frequent in September, and were not observed in February.

Immature males (stage I) occurred at a higher frequency in December, while males in the process of gonadal development (stage II) were more frequent in February. Males with empty gonads (stage IV) were found only after February, while males in the resting period (stage $\mathrm{V}$ ) were more frequent in October and were not found from December on. The frequency of males in the resting period was higher than that of the females. It is important to note that no mature females or males were captured.

Fig. 2 presents the gonadosomatic index. As can be seen, the mean GSI of the females was highest in February, while that of males was highest in February and March, suggesting that spawning occurs in these months.

Fig. 3 presents data on the standard length of the first gonadal maturation, indicating the moment when $50 \%$ of the individuals initiated the maturation process $\left(\mathrm{L}_{50}\right)$, with males showing a length of $536 \mathrm{~mm}$ and females $574 \mathrm{~mm}$, and the standard length at which all individuals are able to reproduce $\left(\mathrm{L}_{100}\right)$, which was $580 \mathrm{~mm}$ for males and $590 \mathrm{~mm}$ for females. The males attained $\mathrm{L}_{50}$ and $\mathrm{L}_{100}$ before the females.

\section{DISCUSSION}

Seasonal reproduction of fishes in flooding areas is closely related to the system's hydrological cycle, with well defined periods of drought and floods. In the dry period, the fish form schools and swim upstream to spawn. According to Fryer

TABLE 1

Number of individuals caught, sex, minimum and maximum standard length of specimens captured monthly during the study.

\begin{tabular}{|l|c|c|c|c|c|c|}
\hline \multirow{2}{*}{ Month } & \multicolumn{3}{|c|}{ Female } & \multicolumn{3}{c|}{ Male } \\
\cline { 2 - 7 } & $\#$ & Ls min. $(\mathrm{mm})$ & Ls max. $(\mathrm{mm})$ & $\#$ & Ls min. $(\mathrm{mm})$ & Ls max. $(\mathrm{mm})$ \\
\hline September/97 & 13 & 350 & 673 & 08 & 362 & 581 \\
\hline October/97 & 17 & 405 & 655 & 24 & 432 & 612 \\
\hline December/97 & 04 & 393 & 582 & 03 & 349 & 532 \\
\hline February/98 & 06 & 492 & 602 & 23 & 381 & 607 \\
\hline March/98 & 06 & 384 & 555 & 14 & 456 & 631 \\
\hline Total & 46 & & & 72 & & \\
\hline
\end{tabular}




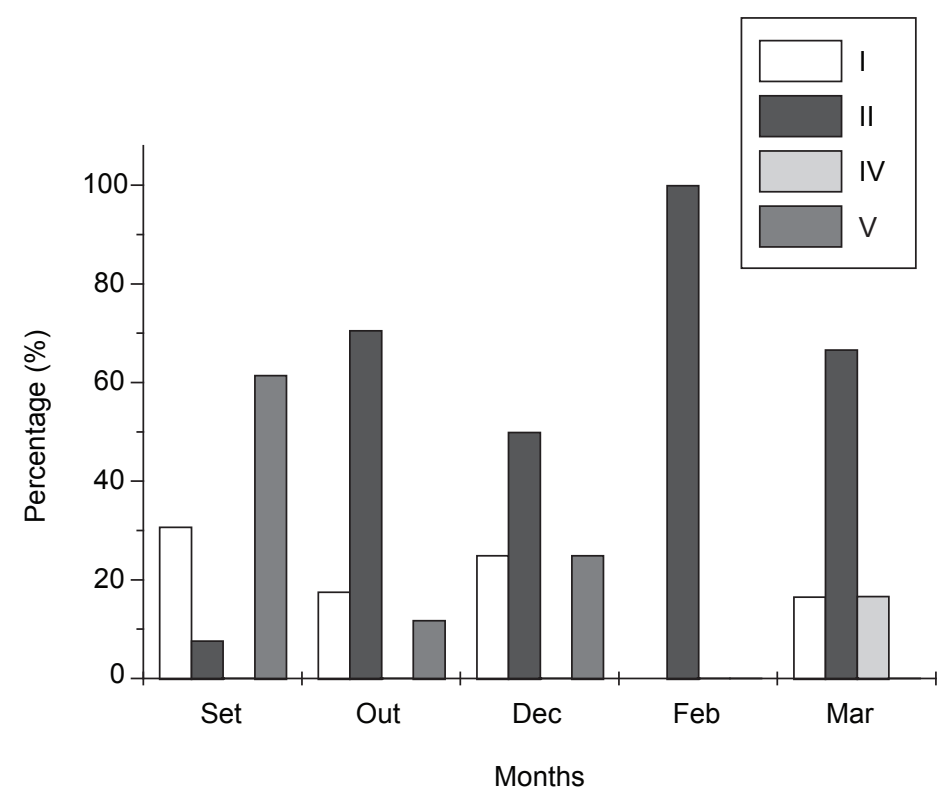

(a)

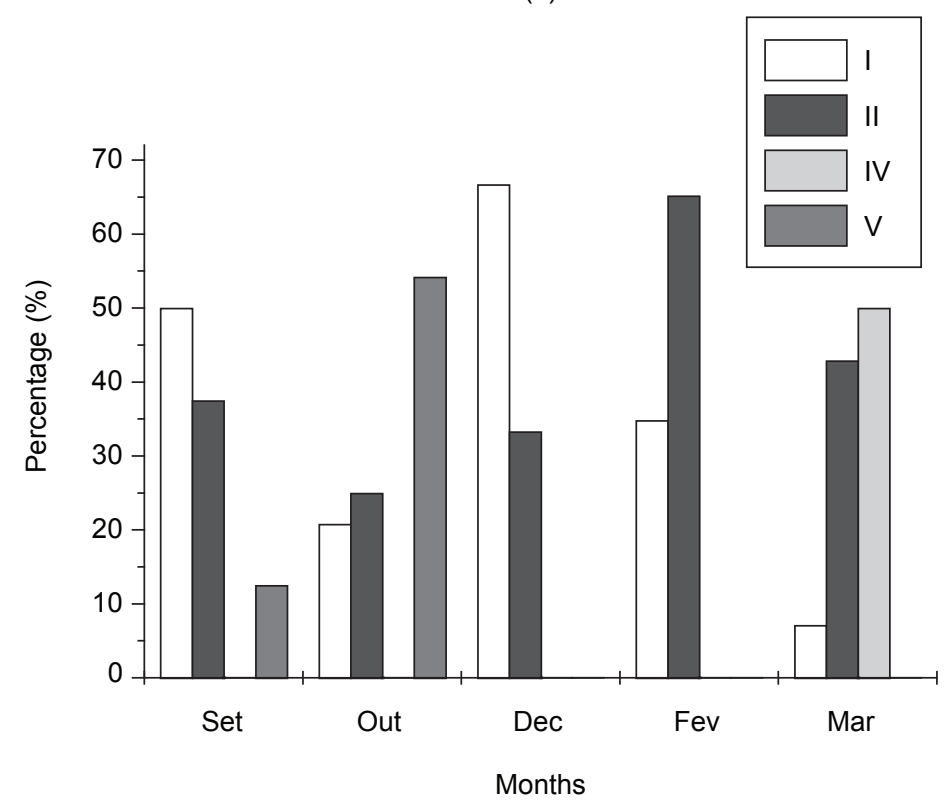

(b)

Fig. 1 - Distribution of stages of gonadal maturation of Pinirampus pirinampu females (a) and males (b). I - immature; II - maturing; IV - empty; and V - resting.

(1965), the migration to spawn is related not only with the protection of juveniles but also to ensure dispersion along the course of the river. McKeown (1984) points out that fish may migrate in order to optimize foraging behavior, avoid unfavorable conditions, increase reproductive success, and promote colonization.
Individuals of $P$. pirinampu in the gonadal maturing process were more frequently found in February, and individuals with empty gonads were observed from that month on. The gonadosomatic index (GSI) increased as of September and peaked in February. Thus, one can infer that the increase in the GSI was constant up to the occurrence of 


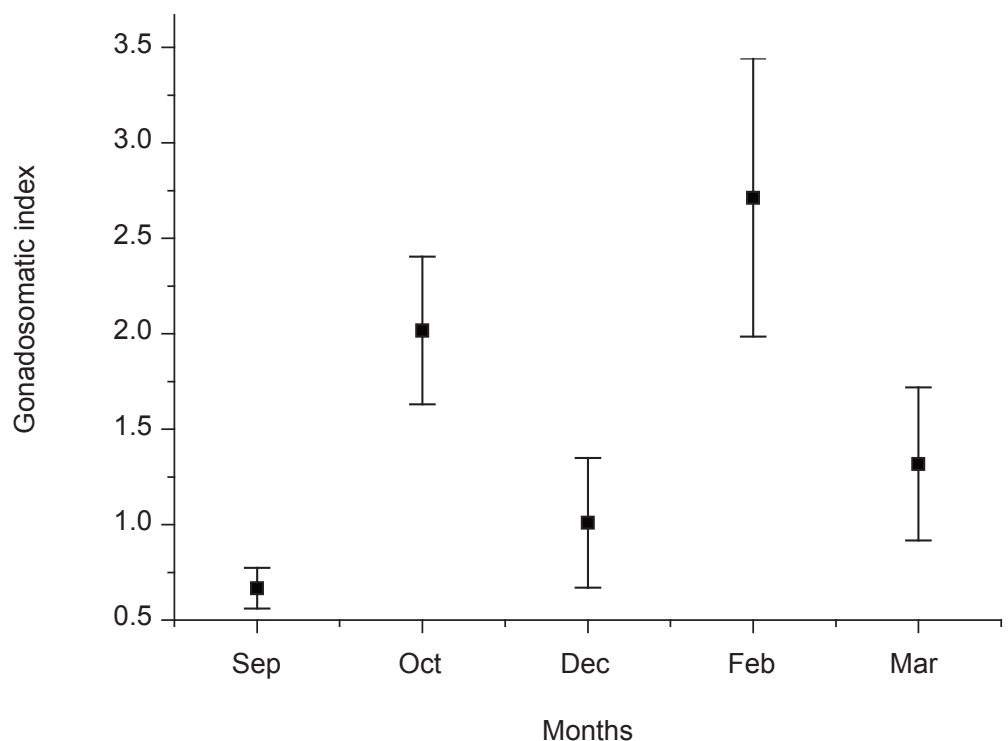

(a)

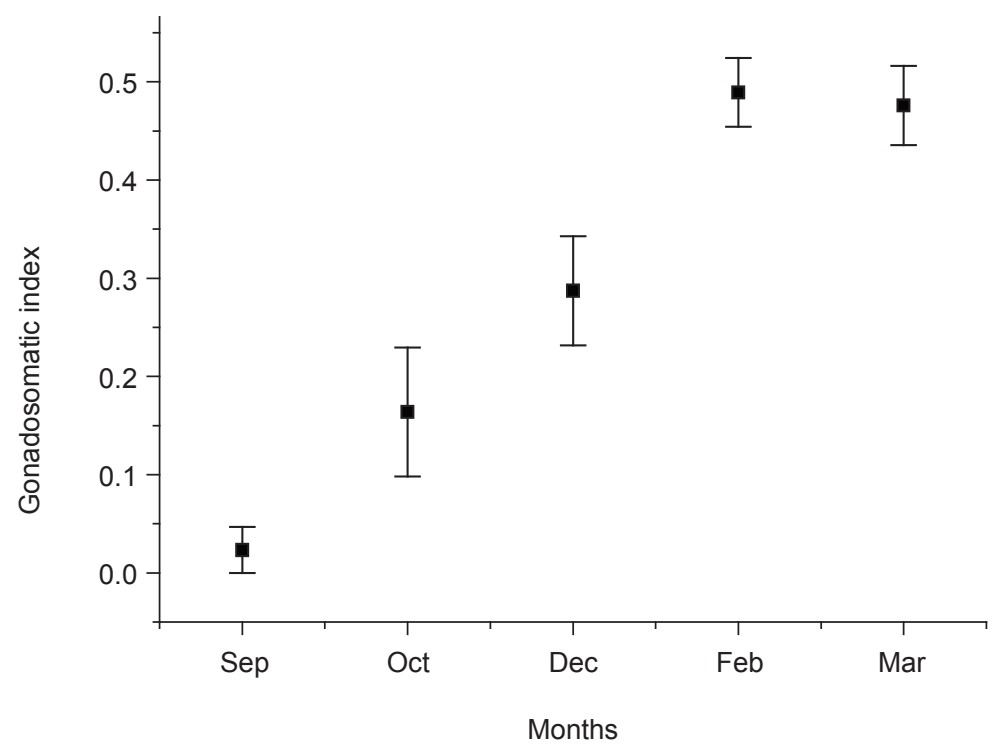

(b)

Fig. 2 - Mean and standard error of the Gonadosomatic index of adult females (a) and males (b) of Pinirampus pirinampu. Period 1997/1998.

spawning in February. These data indicate that spawning took place over a short period of time in February. This behavior is similar to that of other pimelodids in the Pantanal wetlands, such as the pintado (Pseudoplatystoma corruscans) and the cachara (Pseudoplatystoma fasciatum) (Resende et al., 1995).
The beginning of sexual maturation represents a critical period for animals that continue to grow after reaching maturity because, from this point on, a potential conflict is established involving the allocation of resources for survival, growth and reproduction (Wootton, 1990). The first sexual maturation is an important point in the animal's 


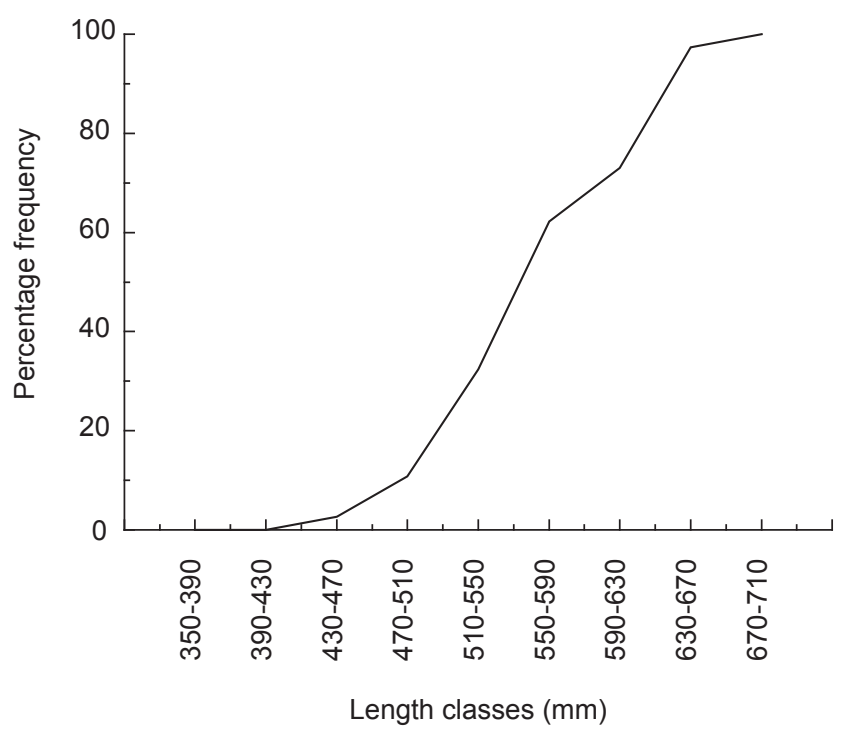

(a)

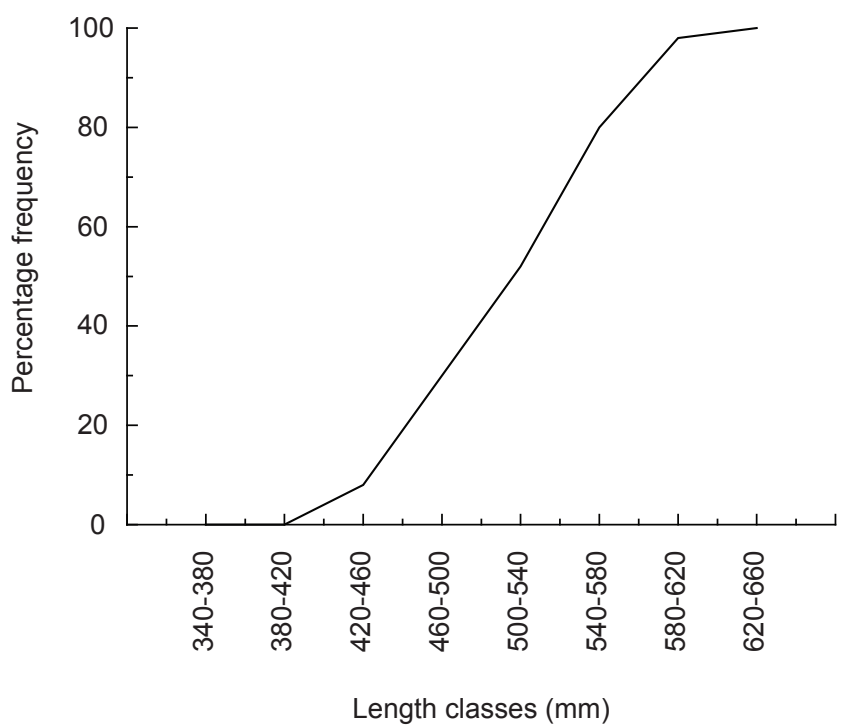

(b)

Fig. 3 - Relative frequency of adult females (a) and males (b) of Pinirampus pirinampu, classified by standard length.

life history and must be taken into account for successful fish management. Furthermore, such information is fundamental for the implementation of measures to prevent the exploitation of young individuals, which, if ignored, could lead to the reduction of the reproductive stock.

For Pinirampus pirinampu in the Tibagi River of Brazil's Paraná River basin, Orsi \& Shibatta
(1996) estimated $\mathrm{L}_{50:} 180$ and $200 \mathrm{~mm}$ (male and female, respectively) and $\mathrm{L}_{100}: 700 \mathrm{~mm}$ for males and females (standard length ). Vazzoler (1992) estimated an $\mathrm{L}_{50}$ of $330 \mathrm{~mm}$ in the upper Paraná River. A comparison of these data with our results, i.e., $\mathrm{L}_{50}: 574 \mathrm{~mm}$ for females and $536 \mathrm{~mm}$ for males, and $\mathrm{L}_{100}: 590 \mathrm{~mm}$ for females and $580 \mathrm{~mm}$ for males (standard length), reveals considerable 
differences in the values of both $\mathrm{L}_{50}$ and $\mathrm{L}_{100}$. These discrepancies may be due to differences in environmental conditions, which possibly anticipate or postpone the species' reproductive process.

Males displayed smaller $\mathrm{L}_{100}$ and $\mathrm{L}_{50}$ than females, and these differences were expected. Vazzoler et al. (1997) also commented on this point, noting that the length (or age) of first gonadal maturation is related with a genotypeenvironment interaction involving intraspecific variations in space and time, which depend on biotic and abiotic conditions. Stearns \& Crandall (1984) discuss the controversy between a fixed size for maturation or a fixed age for maturation, affirming that neither situation is actually true and suggesting that maturation occurs along a pathway of age and size.

Based on the results presented herein, Brazil's Mato Grosso do Sul state government adopted the criterion of $60 \mathrm{~cm}$ (total length) minimum capture size for Pinirampus pirinampu, enacted through Law \# 9768 dated January 13, 2000.

Acknowledgments - We are indebted to Agostinho Carlos Catella for suggesting this study, and to Miguel Petrere Júnior, Francisco M. de Souza Braga and Leandro Muller Gomieiro for their helpful comments on the manuscript.

\section{REFERENCES}

AgOstinho, A. A., JÚlio, H. F. JR., GOMES, L. C., BINI, L. M. \& AGOSTINHO, C. S., 1997, Composição, Abundância e distribuição espaço-temporal da ictiofauna, pp. 179-208. In: A. E. A. de M. Vazzoler, A. A. Agostinho \& N. S. Hahn (Eds), A planície de inundação do Alto Rio Paraná: aspectos físicos, biológicos e socioeconômicos, 460p., EDUEM, Maringá.

BRASIL. Ministério do Meio Ambiente, dos Recursos Hídricos e da Amazônia Legal, 1997, Plano de Conservação da Bacia do Alto Paraguai. PNMA, Brasília, $2^{\circ}$ vol., tomo 3, 433p.

CATElla, A. C., 2001, A pesca no Pantanal de Mato Grosso do Sul, Brasil: descrição, nível de exploração e manejo (1994 - 1999). Tese (Doutorado em Biologia Tropical e Recursos Naturais). Instituto Nacional de Pesquisas da Amazônia, Universidade do Amazonas, Manaus, 343p.

FERRAZ DE LIMA, J. A. F. de L., 1981, A pesca no Pantanal de Mato Grosso-Rio Cuiabá: biologia e ecologia pesqueira, pp. 503-516. Anais do II Congresso Brasileiro de Engenharia de Pesca, Recife.

FRYER, G., 1965, Predation and its effects on migration and speciation in african fishes: a comment. Proc. Zool. Soc. London, Oxford, 144: 301-310.

HARLEY, S. J., MILLAR, R. B. \& McARDLE, B. H., 2000, Examining the effects of changes in the minimum legal sizes used in the Hauraki Gulf snapper (Pagrus auratus) fishery in New Zeland. Fish. Res., 45: 179-187.

LOWE-MCCONNELL, R. H., 1987, Ecological Studies in Tropical Fish Communities. Cambridge University Press, Cambridge, 382p.

MATEUS, L. A. F., 2003, Ecologia da pesca de quatro grandes bagres (Siluriformes: Pimelodidae) na Bacia do Rio Cuiabá, Pantanal Mato-grossense. Tese (Doutorado em Ciências Biológicas, área de Zoologia). Universidade Estadual Paulista "Júlio de Mesquita Filho", Rio Claro, $177 \mathrm{p}$.

McKEOWN, B. A., 1984, Fish migration. Timber Presss, Portland, 224p.

ORSI, M. L., SHIBATTA, O. A., 1996, Determinação do comprimento médio de primeira maturação sexual das 16 espécies principais de peixes do rio Tibagi, PR, pp. 47-48. In: Anais do $3^{\circ}$ Congresso de Ecologia do Brasil. Brasília.

RESENDE, E. K., CATELLA, A. C. NASCIMENTO, F. L., PALMEIRA, S. S., PEREIRA, R. A. C., LIMA, M. S. \& ALMEIDA, V. L. L., 1995, Biologia do Curimbatá (Prochilodus lineatus), Pintado (Pseudoplatystoma corruscans) e Cachara (Pseudoplatystoma fasciatum) na Bacia Hidrográfica do rio Miranda, Pantanal do Mato Grosso do Sul, Brasil. EMBRAPA-CPAP (Boletim de Pesquisa 02), Corumbá, 36p.

STEARNS, S. C. \& CRANDALL, R. E. 1984, Plasticity for age and size at sexual maturity: a life-history response to unaviodable stress., pp. 13-33. In: G. W. Potts \& R. J. Wootton (Eds). Fish reproduction: strategies and tactics. Academic Press, London, 384p.

VAZZOLER, A. E. A. de M., 1992, Reprodução de Peixes, pp. 1-13. In: Agostinho, A. A., Cecilio, E. B. Situação Atual e Perspectivas da Ictiologia no Brasil. EDUEM, Maringá, $127 \mathrm{p}$.

VAZZOLER, A. E. A. de M., 1996, Biologia da reprodução de peixes teleósteos: teoria e prática. Maringá, EDUEM, São Paulo, SBI, 169p.

VAZZOLER, A. E. A., de M., SUZUKI, H. I., MARQUES, E. E. \& LIZAMA, M. A. P., 1997, Primeira maturação gonadal, períodos e áreas de reprodução, pp. 249-265. In: A. E. A. de M. Vazzoler, A. A. Agostinho, Hahn, N. S., A Planície de Inundação do Alto Rio Paraná. Maringá, EDUEM, 460p.

WOOTTON, R. J., 1990, Ecology of Teleost Fishes, Chapman \& Hall. London, 404p. 